\title{
Teaching Competence of Public-School Teachers in the Light of the Philippine Professional Standards for Teachers
}

\author{
Rodelyn E. Malunes ${ }^{1}$ and Dexter Paul D. Dioso ${ }^{2}$ \\ ${ }^{1}$ Patricia Homes Elementary School, Bacolod City, Philippines \\ ${ }^{2}$ University of Negros Occidental-Recoletos, Bacolod City, Philippines
}

\begin{tabular}{l} 
Article history \\
Submitted: 13 July 2020 \\
Revised: 2 November 2020 \\
Accepted: 12 November 2020 \\
\hline Keywords: \\
Education \\
Management \\
Teaching Competence \\
Professional Standards \\
Public School Teachers \\
Descriptive-Comparative \\
Bacolod City
\end{tabular}

Introduction. The teaching competence of teachers is highly regarded as the core of every educational endeavor. Educators worldwide are greatly challenged to gradually develop a more complex teaching competence due to the demand for highly skilled graduates in the global market. Consequently, the Department of Education adopted the Philippine Professional Standards for Teachers (PPST) as a quality assurance tool in implementing the $\mathrm{K}$ to 12 Curriculum. The domains of the PPST comprised the complete competency that guarantees a manifestation of globally best teaching practices (Petalla \& Madrigal, 2017; Roberto \& Madrigal, 2018). Hence, the paper assessed the level of teaching competence of public elementary school teachers in the Division of Bacolod City during the school year 2019 - 2020, when grouped according to educational attainment, teaching experience, and assessor's designation. Also, it analyzed whether a significant difference exists in the areas of teaching competence and demographics.

Methods. The study is quantitative research, making use of descriptive and inferential analyses. The respondents were the whole population of teachers at public elementary school in District III, Division of Bacolod City. The standardized survey questionnaire of the PPST was used to gather the data. The statistical tools used to analyze the data are Mean, Standard Deviation, Wilcoxon Signed-Rank Test, Mann Whitney U Test, and Kruskal-Wallis.

Results. The findings of the study revealed that the level of teaching competence of public elementary school teachers was very high regardless of the demographic profiles. In terms of the domains, learners' diversity, curriculum and planning, and content knowledge and pedagogy have the lowest mean scores. Moreover, it exposed a non-statistically significant difference in the level of teaching competence in the seven domains when teachers were grouped according to educational attainment and teaching experience. Furthermore, when grouped according to assessors' designation, a nonsignificant difference in the level of teaching competence and content knowledge and pedagogy, diversity of learners, assessment, and reporting, and community linkages and professional engagement. Conversely, a statistically significant difference was found in the level of teaching competence and the areas of learning environment, curriculum and planning, and personal growth and professional development.

Conclusion. The teaching competence of public elementary school teachers is viewed as a significant ingredient for a commendable delivery of quality instruction to the $21^{\text {st }}$-century learners, a benchmark from the global standards for quality education. It is a noteworthy orientation of teachers of owning accountability for personal growth and professional development. Significantly, school administrators play an essential role in enhancing the skills, knowledge, and attitudes of their subordinates. Similarly, the teaching and learning endeavor soar higher among the globally best through teachers whose zeal is pursuing lifelong professional development. Also, it can be accounted that teaching competence is supposedly developing gradually to its finest over time as the teacher accumulates sufficient teaching experiences. As an agent of change and molding, not just the mind but the holistic aspects of human being, it requires rigid scrutiny of the teachers' teaching competence to ensure compliance and commitment to the set standards. This is rightful because teaching is above all other professions, and teachers are held up high on the pedestal. 
Practical Value of the Paper. The study is viewed as significant to future research dealing with the teaching competence of public elementary school teachers based on the PPST. Likewise, the findings contributed baseline data for principal and supervisor in designing a professional development plan that addresses the teachers' identified areas for continuous improvement.

\section{References}

Goldhaber, D. \& Anthony, E. (2003). Indicators of Teacher Quality. ERIC Clearinghouse on Urban Education. ERIC Digest. www.ericdigest.org/2004-1/quality.htm

Kane, T., Rockoff, J. Staiger, D. (2007). Photo Finish: Certification Does not Guarantee a Winner. Education Next. http:// www.educationnext.org

Kavinda, U. \& Yan Ye. (2015). A Study of Teachers' Competence of Two High Schools in Northern Rakhine (Arakan) State, Western Myanmar. Graduate School of Education, Assumption University of Thailand

Gorman, L. (2007). Good Teachers Raise Student Achievement. National Bureau of Economic Research Digest Online. Aug. 2005. 13 Aug. 2007. Retrieved from http://www.nber.org/digest/aug05/w11154.html

Leyaley, R.G. (2016). Cooperating Teachers Competence along with the National Competency-Based Standards (NCBTS), Kalinga Division. International Journal of Advanced Research in Management and Social Sciences. ISSN: 2278-6236

Pa-alisbo, M.C. (2017). The $21^{\text {st }}$ Century Skills and Job Performance of Teachers. St. Theresa International College Nakhon Nayok, Thailand. Journal of Education and Practice. ISSN: 2222-1735 (Paper) ISSN 2222-288X (Online). Vol. 8, No. 32, 2017

Petalla, M.B. \& Madrigal, D.V. (2017). Teaching Standards Competence and Efficiency Performance of the Basic Education Teachers. University of Negros Occidental-Recoletos, Bacolod City, Philippines. Journal of Institutional Research in South East Asia - Vol. 15 No. 3 Dec 2017

Philippine Professional Standards for Teachers. (2017). Department of Education-Teacher Education Council. Republic of the Philippines.

Roberto, J. \& Madrigal, D. V. (2018). Teacher Quality in the Light of the Philippine Professional Standards for Teachers. University of Negros Occidental-Recoletos, Bacolod City, Philippines. Philippine Social Science Journal - Vol. 1 No. 1 July-December 2018

Walsh, K. (2006). Teacher Certification Reconsidered: Stumbling for Quality. The Abell Foundation. Baltimore: The Abell Foundation, 2001.21 June 2006. www.abell.org/pubsitems/ed_cert_rejoinder_1101.pdf

\section{Correspondence:}

Rodelyn E. Malunes [rodelyne.malunes@yahoo.com]

http://orcid.org/0000-0001-6231-621X 